\title{
Womanspirit Still Rising? Some Feminist Reflections on 'Religious Education' in the UK
}

\author{
Alison Jasper
}

\begin{abstract}
It is a complex and sometimes frustrating business to effect change that is in accordance with recognizably feminist principles in the world as it is and we inevitably risk confrontation, misunderstanding and compromise. In this paper I consider some of the complexities and obstacles to effecting feminist-friendly changes in educational spaces with specific reference to the field of teaching most familiar to a majority of us Religion/Religious Studies or Theology and Religious Studies (TRS). I suggest an approach to change based on the mobilization of spirituality - characterized as becoming - as one metaphor that has been grasped to effect in the past by pioneers such as Carol Christ and Judith Plaskow to bring about changes in the western theological academy. This imaginative work has itself generated resistance and critique from scholars of religion and some feminists, but remains, I believe, one fruitful starting point for thinking through what needs to change in educational spaces identified as 'religious', and how to avoid the gendered traps that are laid for us in the process. Primarily these are traps that frustrate our abilities to explore the widest possibilities of difference/s and lead us back into the constrictions of sameness - here, that state of being tied either to a historical view of Christianity that privileges a disembodied, masculine, monotheistic God or to a post enlightenment view that privileges a disembodied, so-called 'secular' masculine rationality that just as fearfully excludes the Otherness of the feminine and all she represents.
\end{abstract}

\section{Keywords}

Feminism, religion, spirituality, teaching religious studies

\section{Setting the Scene}

Women's efforts within local, national or global structures to change hegemonic male cultures of work and worth, seem slow to take real and constructive shape and, as femi- nist scholars and writers, our work and practice is often compromised by the institutions and relationships we service even as we try to critique and contest them. The corrosive corporatization and marketization of Higher Education, for example, is something many academic women (often alongside their male colleagues, it has to be said) struggle, meaningfully to resist given that in terms of the current corporate and still definitively masculinist zeitgeist of public policy making, emphasis on efficient use of resources and the satisfaction of 'customers' (students or external stakeholders) increasingly 
sidelines investment in genuine open-ended research, teaching and innovation ${ }^{1}$ as 'institutions devote more resources to compliance and learning to "play the [corporate] game". ${ }^{2}$

With an eye to Religious Education as one practical and policy context within which we might propose there could be a programmatic concern with marginal knowledges and with calling the totalizing zeitgeist referred to above into question, this paper seeks to look at how feminist ideas and analyses might help expand capacity for engaging with difference/s in public spaces identified with education, and articulate in this sense some important alternate and transformative visions. First, of course, it is important to clarify some of the terms being used and indicate their range of reference. For example, 'reli- gious education' could be used to refer to a huge range of contexts from Madrassas to the Science Museum and from sitting on our mother or father's knees to attending a semi- nary or completing an on-line 'training course' in equality and diversity awareness. In this context, the focus will be the narrower 'subject areas' of Religious Education/ Religious Moral Education /Religious Moral Philosophical Studies/Religious Studies in the public spaces of secondary schools and of Theology and Religious Studies (TRS) at higher education level (herafter, collectively, RE). Of course, these are particular and different - spaces and arguably the gap between what it is to study a subject such as 'religion' within a school context and what this involves within a university setting is considerable. ${ }^{3}$ Moreover, working within a Scottish context, the educational system, though comparable in many ways to that in England Wales and Northern Ireland, has historically always valued its distinctiveness and independence from the rest of the UK. Nevertheless, there is still much in terms of institutional and cultural inheritance and

1. See Brown R, Carasso H (2013) Everything for Sale? The Marketisation of UK Higher Education (Research into Higher Education). London \& New York: Routledge; Collini S (2012) What are Universities For? London \& NY: Penguin Books; Mcgettigan A (2013) The Great University Gamble: Money, Markets \& the Future of Higher Education. New York: Palgrave Macmillan.

2. Brown R (2013) Everything for sale. Available at: Council for the Defence of British Universities Blog, r8 April 2013http://cdbu.org.uk/2013/04/. See also Brown R, Carasso H (2013) Everything for Sale? The Marketisation of UK Higher Education (Research into Higher Education). London \& New York: Routledge.

3. See I'Anson J (2004) Mapping the subject: student teachers, location and the understanding of religion'. British Journal of Religious Education 26(1): 41-56. 
current emphasis on corporate management, for example, that links these public spaces identified with education.

It is also important to say something about difference/s. It should not be assumed that by using this term, some kind of determinative set of practices or ideas that are necessarily at odds with current educational policy are advocated. Rather the emphasis on difference/s represents a broad trajectory of critique directed against a western, patriarchal hegemony. Drawing from a jointly authored book project, I together with my co-author, ${ }^{4}$ also charac- terize this approach as one that favours relational over substance-oriented ontologies. Drawing on the work of Wesley Wildman, it could be claimed that newer, relational ontol- ogies are not simply constituted from bodies of knowledge that can be produced and exchanged in precisely measurable quantities, but that the emphasis has shifted to the varied and complex socio-material relations and practices through which particular enti- ties such as 'religion' or 'religious education' - come in to being. 5 These forms of critique and analysis are consciously bound up with ethical questions of purpose and desirability and are used here deliberately to interrogate models for change, profitability or growth ${ }^{6}$ within what might be termed the current context of neoliberalism. ${ }^{7}$

Making reference to this change from substance-oriented to relational terms of refer- ence highlights the way in which conceptual metaphors frame our thinking and actions. Over the last few decades, scholars have established that metaphor is pervasive, ${ }^{8}$ and attending to the metaphors we use in developing policy and practice in educational spaces - in RE spaces - is crucial if we are indeed to change hegemonic cultures of work and worth. In what follows, therefore, I propose to explore the affordances of the meta- phor of 'spirituality' within RE spaces as a means of expanding capacity for engaging with difference/s in public spaces identified with education, and in this sense for articu- lating alternate, transformative - and feminist-friendly - visions.

4. See I'Anson J, Jasper A (forthcoming) Schooling In/difference. London \& NY: Routledge.

5. See Wildman W (2010) An introduction to relational ontology. In: Polkinghome J (ed.) The Trinity and an Entangled World: Relationality in Physical Science \& Theology. Grand Rapids, MI: Eerdmans, 55-73.

6. See, for e.g. Harvey D (2012) Neoliberalism as creative destruction. In: Mansbach RW, Rhodes E (eds) Introducing Gobalization: Analysis and Readings. London: CQ Press, 55-73, 62.

7. See for e.g. McChesney RW (1998) defines neoliberalism as 'the policies and processes whereby a relative handful of private [and predominantly male] interests are permitted to con- trol as much as possible of social life in order to maximise their personal profit'. Introduction to Chomsky N, Profit Over People: Neoliberalism and Global Order. London \& New York: Seven Stories Press, 8.

8. See for e.g. Christ C (1979) Why women need the Goddess: phenomenological, psychologi- cal, and political reflections'. In: Christ C, Plaskow J (eds) Womanspirit Rising: A Feminist Reader in Religion. New York: HarperCollins; McFague S (1987) Models of God: Theology for an Ecological, Nuclear Age. Minneapolis, MN: Fortress Press; Lakoff G, Johnson M (1980) Metaphors We Live By. Chicago, IL: University of Chicago Press; le Doeuff M (1989) The Philosophical Imaginary. London \& Stanford, CA: Athlone Press; Stanford University Press. 
At first it might seem doubtful whether these spaces do in fact represent a propitious site from which to begin engaging with marginal knowledges/difference/s or developing this theoretically more feminist-friendly terrain. In the UK, of course, education along- side all other cultural institutions is heir to deeply held assumptions about gender. Arguably these are derived first and foremost from historical Christianity and the idea that women and the feminine are associated with the sinful flesh of humanity and com- pletely eclipsed by the disembodied masculine purity of the divine. Much of the work of early feminist theology in the 1970s and 1980s by key figures such as Rosemary Radford Ruether, Mary Daly and Carol Christ was concerned with articulating this analysis. Also significant is the sense in which an otherwise robust Enlightenment critique of Christianity left earlier assumptions about gender and gender hierarchy largely in place, continuing to privilege masculine-identified disembodied rationality over the feminine-identified body and the vulnerabilities of embodiment. Although arguably, traditions of European liberalism have resulted in practices of gender discrimination being increasingly con- tested and outlawed, this does not mean all of these gendered assumptions have been eliminated. Nor does the fact that girls and women are not formally discriminated against mean, for example, that men and women are untouched by gender conditioning. In our contemporary context

...[a]s soon as we are born (perhaps even before) we are color coded as boy or girl, and systematically trained according to our genders. Our rooms are painted sky blue and decorated with mobiles of toy planes, or rose pink and decorated with flowers.... ${ }^{9}$

Another factor about UK RE today that might be seen as problematic for the project of articulating alternate visions in terms of spirituality/ies, is the effect of formative changes made during the 1970s by scholars identified principally with Ninian Smart. Seizing the initiative opened up by apparently decreasing public conviction or interest in Christianity, Smart and his colleagues made a highly successful bid to claim public RE spaces in schools and Universities for a new and different understanding of 'religion.' In directing their attention to 'religion' in education, Smart and his colleagues envisaged children and young people engaging with a much broader and more ambitious range of historical and cultural contexts, objects, texts and practices than had been common prior to this period in RE spaces. The notion of 'world religions' now almost universally referenced in UK RE, derives from Smart's work on what he called 'religious experience' 10 and from the work of the Shap working party on World Religions in Education of which he was a founding member. ${ }^{11}$ In this way, Smart and his colleagues sought to increase awareness of different ways of thinking and being and to challenge the previously exclusive privi- lege of the Christian Churches within these public RE spaces in terms of a vision that seemed at the time to be highly 'alternate'. However, and aside from the fact that the work of Smart and others of his circle 
9. Chanter T (2006) Gender: Key Concepts in Philosophy. London \& New York: Continuum, 3.

10. Smart N (1969) The Religious Experience of Mankind ( New York: Scribner.

11. Available at http://www.shapworkingparty.org.uk/history.html. Last accessed 11 September

did not pick up on the insights of feminist theorists that were beginning to surface at the same period, the original energizing vision of this work appears to have stablized if not stagnated over the last 40 years in line with the

growth of what Patti Lather has called

'...a world wide audit culture with its governmental demands for evidence based practice and the consequent (re)privileging of scientistic methods'. ${ }^{12}$

In other words, 'world religions' in spite of appearing to reference the widest possible forms of difference/s seems to have become increasingly aligned with a much more recognizable, examinable framework that references Smart's signatory religious 'dimensions' 13 as a way of categorizing and thus essentializing 'religion'. The intention was undoubtedly to make diverse cultural and philosophical complexity more accessible to a UK and North American readership in order to expand awareness and promote empathy. Yet in effect, the approach has also tended to bring extraordinarily different experiential and ontological perspectives into line with a strongly western 'official account of reli- gion'. ${ }^{14}$ This official account operates through simplifications, for example, in references to the world's 'six major religions (i.e. Buddhism, Christianity, Hinduism, Islam, Judaism and Sikhism)' 15 and to 'non-religious' perspectives glossed as 'secular'. ${ }^{16}$ These kinds of measurable bodies of knowledge are much easier to contain within policy initiatives than are the - perceived by the modern state as dangerous - goals of confessional Christianity or Islam, or the kinds of much more open ended and unpredictable engagements envi- sioned in our (the authors, as previously referenced) vision for public educational spaces identified with UK RE. Of course, yielding to the pressures exerted by an increasingly corporatized educational institution has paid some dividends for RE professionals. For example, a greater emphasis on preparation for formal academic examination of an RE option - as opposed to a non-examinable, compulsory RE - has allowed them to present their subject area more strongly in terms of the official account; one that students can choose and schools, colleges and universities can resource in alignment with current mainstream educational aims and priorities. Given that there is, nonetheless, still a lively debate about whether 'religion' should be addressed at all in public schools in the UK - at present (2015) it is still compulsory - pressure on RE professionals to conform to this conceptual framework in the interests of survival within the curriculum, is all the more intense. But these tendencies are not conducive to the kind of openness to difference/s that this project aims to engender 
12. Lather P (2007) Getting Lost: Feminist Efforts Toward a Double(d) Science. Albany NY: SUNY Press, 2.

13. Smart N (1971) The Religious Experience of Mankind. Glasgow: Collins, 15-25.

14. I'Anson J, Alison J (2006) Negotiating religions and cultures in gendered educational spaces'. Discourse 5(2): 78-80.

15. Scottish Qualifications Authority (SQA), Higher Religious, Moral and Philosophical Studies Course Specification, April 2014, Version 1.1. Available at: http://www.sqa.org.uk/files_ccc/ CfE_CourseSpecification_Higher_RMPS_ReligiousMoralandPhilosophicalStudies.pdf

16. See for e.g. SQA, National 5 Religious, Moral and Philosophical Studies Course Support Notes, April 2012, version 1.0. Available at: http://www.sqa.org.uk/files_ccc/CfE_ CourseUnitSupportNotes_N5_RMPS_ReligiousMoralPhilosophicalStudies.pdf

through the exploration of the metaphor of spirituality.

There is yet another reason for wondering whether these RE spaces are the most pro- pitious for engaging with marginal knowledges/difference/s and developing a more fem- inist-friendly conceptual terrain for alternate visions in terms of spirituality/ies. Whilst this discussion is identified with the word 'religion' as in $\mathrm{RE}$, the term is generally being used - as it were - inside scare quotes. It has been argued, ${ }^{17}$ that, following on from the European Enlightenment, a gendered and hierarchical ${ }^{18}$ binary between 'religion and the secular' having been established, aspects or elements of experience that might have criti- cal bearing on the public spaces of so-called 'secular' government and policy making were subsequently bracketed under the devalued heading of 'religion'. Those who take this view argue that the binary distinction developed from the $17^{\text {th }}$ century onwards in order to enable pioneering scientific, commercial and non- conforming Christian communities to prise themselves loose from the constraining imaginary of a sovereign state bound by the notion of Christian Truth. ${ }^{19}$ However, this binary encourages the view that 'secular' western notions of democracy, science and capital, for example, are the defin- ing, forward-looking characteristics of prosperity, sanity and global security whilst rul- ing powerful 'religious' - that is, understood as arbitrary and irrational - motivations out of court. In consequence it also serves to maintain distrust of women and the feminine in line with these associations.

A final factor militating against the development of RE UK spaces as contexts for engaging with marginal knowledges/difference/s and for trying to develop new concep- tual metaphors and alternate visions, is an increasingly skeptical turn away from cultural diversity and/or multiculturalism ${ }^{20}$ as beneficial. In RE UK spaces the impact of wide public disquiet about 'extremism' that poses a threat to liberal political assumptions ${ }^{21}$ is to make policy makers as much concerned with the dangers of exposing children and young people to difference/s - for example, in terms of Muslim radicalization ${ }^{22}$ - as with

17. See Fitzgerald T (2007) Encompassing religion, privatized religions and the invention of modern politic. In: Fitzgerald T (ed.) Religion and the Secular: Historical and Colonial Formations. London \& Oakville CT: Equinox Publishing, 211-40. 
educational spaces. Feminist Theology .

19. Fitzgerald T ', (2007) Encompassing religion, privatized religions and the invention of modern politic. In: Fitzgerald $\mathrm{T}$ (ed.) Religion and the Secular: Historical and Colonial Formations. London \& Oakville CT: Equinox Publishing, 212.

20. See Jasper A (forthcoming 2015) 'RE/RME/TRS' is a girl's subject: talking about gender and the discourse of 'religion' in UK educational spaces. Feminist Theology.

21. See Peters MA, Besley T (2014) Editorial: Islam and the end of European multiculturalism: from multiculturalism to civic integration. In: Policy Futures in Education 12(1): 1-15. Available at: http://dx.doi.org/10.2304/pfie.2014.12.1.1; Coppock V, McGovern M (2014) 'Dangerous minds?' Deconstructing counter-terrorism discourse, radicalisation and the 'psychological vul- nerability' of Muslim Children and young people in Britain. Children \& Society 28(3) (2014): 242-56. Available at: http://onlinelibrary.wiley.com/doi/10.1111/chso.12060/abstract

22. See for e.g. HM Government. (2013) Tackling Extremism in the UK: Report from the Prime Minister's Task Force on Tackling Radicalisation and Extremism. Available at: https://www.

gov.uk/government/uploads/system/uploads/attachment_data/file/263181/ETF_FINAL.pdf. This report identifies schools and universities as contexts - alongside prisons - as particularly conducive to promoting Muslim radicalization.

promoting education as a way to move towards the unfamiliar in a positive way as towards transformational experience for the common and individual good. The growth of citizenship studies as an academic discipline, ${ }^{23}$ and as a subject offered in schools according to the English National Curriculum for example, ${ }^{24}$ (in comparison, RE seems increasingly neglected in schools ${ }^{25}$ and in some decline at University level), suggests a desire above all to shore up a common and normative sense of values in order to produce what Bridget Anderson has called a fairy tale 'community of value' ${ }^{26}$ for which integra- $\operatorname{tion}^{27}$ in alignment with the normative is the ideal. Resisting the process of turning difference/s into hostile 'otherness' is thus inevitably deprioritized. In sum then, there appear to be a daunting range of disincentives to fashioning these RE spaces as places in which children and young people, not to speak of educators and other stakeholders, could in some way experience and grow from an encounter with difference/s or with the awkwardness and disconcertment ${ }^{28}$ that informs us we have been genuinely touched by or awakened to something different from what we knew - or thought we knew already.

\section{Spirituality ...}

However RE arguably remains in practice a space where there is concern with marginal knowledges and with calling the totalizing zeitgeist - supported by its traditional mascu- linist metaphors and conceptual frameworks - into question. Its own increasing margin- alization in other words may be as indicative of this disruptive potential for engagement with difference/s and alternate visions as of any genuine waning of interest generally. This paper will now turn back to spirituality as one exemplary concept, model or meta- phor for feminist-friendly thinking in educational spaces that has the capacity to flourish within these RE contexts, expanding - when it is strongly defended - public capacity for understanding the implications of difference/s and articulating in consequence 
some important and transformative visions.

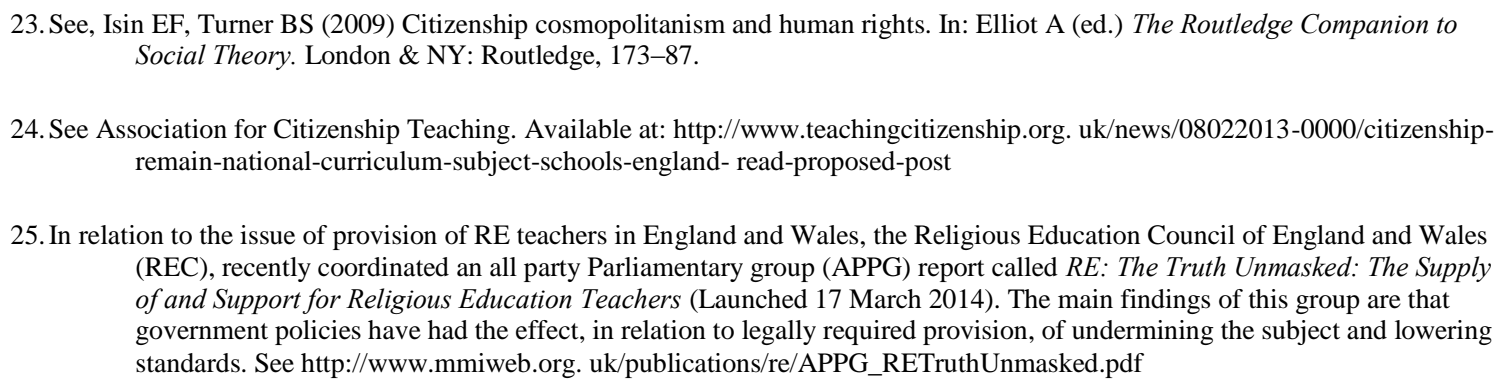

24. See Association for Citizenship Teaching. Available at: http://www.teachingcitizenship.org. uk/news/08022013-0000/citizenshipremain-national-curriculum-subject-schools-england- read-proposed-post

25. In relation to the issue of provision of RE teachers in England and Wales, the Religious Education Council of England and Wales (REC), recently coordinated an all party Parliamentary group (APPG) report called RE: The Truth Unmasked: The Supply of and Support for Religious Education Teachers (Launched 17 March 2014). The main findings of this group are that government policies have had the effect, in relation to legally required provision, of undermining the subject and lowering standards. See http://www.mmiweb.org. uk/publications/re/APPG_RETruthUnmasked.pdf

26. Anderson B (2013) Us \& Them?: The Dangerous Politics of Immigration Control. Oxford: Oxford University Press, 2.

27. See, HM Government, Tackling extremism in the UK (December 2013), 4, 6. Available at: https://www.gov.uk/government/uploads/system/uploads/attachment_data/file/263181/ETF_FINAL.pdf

28. Law J, Lin W-L (2009) Cultivating Disconcertment, 23 December version. Available at: http://www.heterogeneities.net/publications/LawLin2009CultivatingDisconcertment.pdf

Once again however, before we start, it is important to be aware that spirituality as a metaphor that affirms the very fundamental physical breath of life, has itself a long his- tory and in a way similar to the other terms to which reference has already been made, is sometimes caught up in problematic frames of reference. The English word 'spirituality', derived from the biblical Greek and Latin - an etymology shared at least by most of the so-called 'romance' 29 languages indicated within our Christian past, a contrast 'with 'fleshly' meaning 'worldly or contrary to God's spirit', and implied a distinction between 'two approaches to life', ${ }^{30}$ that were clearly related to each other in hierarchical and gen- dered terms to the disadvantage of women and the feminine.

Moreover, whilst for many people today, spirituality is frequently

... taken to denote the positive aspects of the ancient religious traditions, unencumbered by the "dead hand" of the Church, and yet something which provides a liberation and solace in an otherwise meaningless world, ${ }^{31}$

some scholars argue persuasively that the term has been exploited to address a power- fully neoliberal agenda. According to this view spirituality has been thoroughly privat- ized and Carrette \& King's conclusions, about consumeroriented and individulized spiritualities, for example, are disturbing:

...we are now seeing the corporatization of spirituality that is the tailoring of those individualized spiritualities to fit the needs of corporate business culture in its demand for an efficient, productive and pacified workforce... ${ }^{32}$

They identify the vagueness and ambiguity ${ }^{33}$ of the term in current speech as one of the reasons it has wide appeal, both to those who regard themselves as 
'religious' and those who do not. However, whilst from Carrette \& King's perspective this points to an 'opera- tional neutrality' with advantages for corporate marketing purposes, ${ }^{34} \mathrm{a}$ brief review of the discourse of spirituality within educational policy documents in the UK going back into the 20th century seems to suggest the vagueness and ambiguity of the term has had other advantages as well; advantages that weaken the case for adopting spirituality as a metaphor of provocation characterizing a distinctively feminist-friendly vision.

Thus although it appears, for example, that the spiritual has 'had a place in state edu- cation since the involvement of the churches in the national system of education in the

29. See Alkire T, Rosen C (2010) Romance Languages: A Historical Introduction. Cambridge: Cambridge University Press.

30. Sheldrake P (2012) Spirituality: A Very Short Introduction. Oxford: Oxford University Press, 4.

31. Carrette J, King R (2005) Selling Spirituality: The Silent Takeover of Religion. London \& New York: Routledge, 1.

32. Carrette J, King R (2005) Selling Spirituality: The Silent Takeover of Religion. London \& New York: Routledge, 29, the emphasis is mine.

33. Carrette J, King R (2005) Selling Spirituality: The Silent Takeover of Religion. London \& New York: Routledge, 47.

34. Carrette J, King R (2005) Selling Spirituality: The Silent Takeover of Religion. London \& New York: Routledge, 48.

first half of the $19^{\text {th }}$ century', ${ }^{35}$ in $19^{\text {th }}$ and $20^{\text {th }}$ century contexts, 'spirituality' or 'the spiritual' has often implied little more than the desirability of inculcating broadly Christian values ${ }^{36}$ or in other words, socializing children and young people according to the normative, not very thought-through attitudes and perceptions of the time. The Preamble to the 1944 Education Act states that the education provided under its auspices will address the child in terms of his or her 'spiritual', alongside 'moral, mental and physical' development, but here again, it appears that the term was probably chosen not for its rich and varied implications in terms of creative possibilities or capacity for addressing 'the other', so much as for its vagueness that, in contrast with the term 'reli- gion' would not provoke strong disagreements between different Christian and free thinking stakeholders. ${ }^{37}$ In the subsequent Education Reform Act of 1988, concern for the spiritual development of both pupil and society are restated, but there is no clearer sense here of what this term implies apart from its contextualization within the compulsory provision of RE. ${ }^{38}$ So the vagueness and ambiguity of the term 'spirituality' has arguably served a normative agenda in the past, enabling policy makers to appear to be addressing public concerns about shared values in schools ${ }^{39}$ without having to raise the spectre of denominational, racial or sectarian hostility. And in this sense, it appears to have been successfully mobilized: there have always been those who opposed compul- sory Religion in UK schools of course and rejected its assumed relationship with moral- ity and the common good, but the numbers of 
those committed enough to have their children taken out of RE has generally been very small.

However, given the increased emphasis on forms of assessment that require specific and evidential reference to confirm or measure success, the usefulness of the term as a means of glossing over a potential area of dissention has diminished. Policy in relation to spirituality has been pushed to identify itself much more specifically. For example, in the Ofsted report of 2004 on promoting the spiritual, moral, social and cultural develop- ment of pupils there is a very conscientious attempt to avoid identifying spiritual devel- opment with 'religion' and to define it more distinctively as

the development of the non-material element of a human being which animates and sustains us and, depending on our point of view, either ends or continues in some form when we die. It is about the development of a sense of identity, self-worth, personal insight, meaning and purpose.

35. Erricker C, Erricker J (2000) Reconstructing Religious, Spiritual and Moral Education. London \& New York: Routledge Falmer, 36.

36. Erricker C, Erricker J (2000) Reconstructing Religious, Spiritual and Moral Education. London \& New York: Routledge Falmer, 36.

37. Erricker C, Erricker J (2000) Reconstructing Religious, Spiritual and Moral Education. London \& New York: Routledge Falmer, 36.

38. See DFE. Religious Education and Collective Worship 1/94, 31 January 1994, 9. Available at:

http://www.secularism.org.uk/uploads/re-and-collective-worship-circular-1-94.pdf; See also Erricker C, Erricker J (2000)

Reconstructing Religious, Spiritual and Moral Education. London \& New York: Routledge Falmer, 37.

39. See Besley T (2005) Foucault, truth telling and technologies of the self in schools. Journal of Educational Enquiry 6(1) (2005): 76.

It is about the development of a pupil's "spirit". Some people may call it the development of a pupil's "soul"; others as the development of "personality" or "character". 40

While this definition clearly seeks to do more than simply evade the risks - for policy makers - of lining spirituality up too closely with confessional forms of Christianity or, perhaps more recently also with Islam for example, it fails, arguably, to do this conclu- sively - here surely is still the impress of a historical Christian ambivalence about mate- riality, for example - and what emerges as spirituality is, in the end, clearly a matter of privatized individual subjectivity rather than, for example the animating principle of the whole school or of the processes of education itself. And, of course, whilst the authors of this Ofsted report may be right in saying that it is possible to stipulate certain outcomes, it is less obvious whether these exemplify anything more than the normative nature of a certain kind of 'good citizenship' within a school whose aims and objectives are more generally being determined by the current corporate mind-set of current public policy making with, as already suggested, an emphasis on efficient use of 
resources and the satisfaction of 'customers' (students or external stakeholders) over a more open-ended direction of travel.

To be useful in developing alternate and feminist-friendly visions within public edu- cational spaces, the metaphor of spirituality needs then to transcend these limiting inter- pretations that lead back into constructions of sameness - here, the state of being tied either to a view that privileges a disembodied, masculine, monotheistic God or the dis- embodied, so-called 'secular' masculine rationality that just as fearfully excludes the Othernessness of the feminine in its conformity to the conceptual worlds of current cor- porate policy-making structures.

\section{Strengthening Spirituality}

Fortunately there are precedents for taking up the metaphor of spirituality in this trans- formational frame of reference. Whilst some feminists have aligned themselves with the so-called secular, rejecting 'religion' as a set of irredeemably patriarchal structures, oth- ers have resisted these polarizing assumptions that would tend to keep women and the feminine, in view of the gendered nature of the religion/secular binary, in their place and out of the public domain. One approach has been to understand embodiment through the mode of spirituality, deconstructing Christianity's ambivalence about sex and the body ${ }^{41}$ by drawing attention to and owning the vigour of physical life, and breath to which spirituality metaphorically refers. Though it had its limitations in intersectional terms, Carol Christ and Judith Plaskow's 1979 collection Womanspirit Rising was an important early text in this respect. Taking up the challenge by defiantly bringing woman and spirit

40. Office for Standards in Education (Ofsted), March 2004. Available at: http://www.ofsted.gov. uk/resources/promoting-andevaluating-pupils-spiritual-moral-social-and-cultural-develop- ment, download page 12.

41. See Jasper A (2007) Word and body. In: Hass A, Jasper D, and Jay E (eds) Oxford Handbook of English Literature and Theology. Oxford: Oxford University Press, 776-92.

together in the title, they started to break down conventional assumptions that Christian theology had an unassailable privilege in university educational spaces where there was, at the time, no place for women or their unsettling bodies, feelings and desires, and little appetite for challenging prevailing hegemonies in ways that would accommodate them. ${ }^{42}$

In order to unlock the full power of spirituality as a metaphor resonating with a force for life and connectedness with the physical body as well as with that which both trans- forms and transcends the gendered individual, this paper proposes incorporating Rosi Braidotti's work on the pragmatic philosophy of 'becoming woman'; an imaginative strategy based on the understanding that there is no essentialized, sexual difference defining women, but that difference/s are located 
in spaces of 'experimentation by women of their desires and specific sexual morphology'. For Braidotti, 'becoming woman' is an 'escape from ... sameness here, identification with the dominating struc- tures of male phallicity'. ${ }^{43} \mathrm{Her}$ model, of the nomadic then, is proposed here as a way of illustrating movement that is not one-directional or linear but exploratory and experi- mental. Carol Christ's alternate vision of spirituality in Womanspirit Rising (1979) - most radically, of course, in terms of its emphasis on the figure of the Goddess - is at once provocative and incorporative of difference/s; taking into account and challenging the legacy of Christian ambivalence about the body as a hindrance to spirituality but also, through its metaphorical references to breath and physical life, reconnecting female bod- ies and embodiment within this narrative, with 'life, death, and rebirth energy in nature and culture, in personal and communal life'. ${ }^{44}$ Arguably the work of Christ and others from the 1970s onwards helped to bring about a significant change in the psychological and political mood of the western world with effects that have born fruit in growing opportunities for women and girls to engage with a female heritage ${ }^{45}$ that was previously restricted within both Christian and Enlightenment visions of it as a purely hostile 'other- ness'. Yet this movement is clearly not resolved or completed. Christ and her fellow editor note for example in a later edition of this ground-breaking collection of essays, the 'glaring deficiency' of their failure, under the heading of 'womanspirit' to note the ethi- cal implications of intersectional difference/s between women with different racial, sex- ual and social experiences or to allow their voices to be heard. ${ }^{46}$ Yet, given all that has been said above in cautionary terms, intense reflections on purpose and desire will undoubtedly continue to be invoked against the constraints of normative assumptions

\footnotetext{
42. Christ C, Plaskow J (eds) (1992) Womanspirit Rising: A Feminist Reader in Religion. New York: HarperSanFrancisco, vii.

43. Braidotti R (2002) Metamorphoses: Towards a Materialist Theory of Becoming. Cambridge \& Malden, MA: Polity Press, 28.

44. Christ C (1979) Why women need the Goddess: phenomenological, psychological, and politi- cal reflections', In: Christ C, Plaskow J (eds) Womanspirit Rising: A Feminist Reader in Religion. New York: HarperCollins, 278.

45. Christ C (1979) Why women need the Goddess: phenomenological, psychological, and politi- cal reflections'. In: Christ C, Plaskow J (eds) Womanspirit Rising: A Feminist Reader in Religion. New York: HarperCollins, 286.

46. Christ C, Plaskow J (eds) (1992) Womanspirit Rising: A Feminist Reader in Religion. New York: HarperSanFrancisco, viii.
}

and limiting conceptual frameworks. In these contexts, the metaphorical associations between spirituality and life-sustaining physical energies may perhaps be newly recon- nected with transformative exploration and experimentation; becoming different. In bell hooks' words, education is 'the practice of freedom', ${ }^{47}$ that is the opening up of spaces and the antithesis of normalizing stereotypes. In line with the practice of freedom, spir- ituality in the sense suggested here is a positive orientation towards difference/s allowing ideas of purpose and meaning constantly to transform as one perspective is folded into another producing within 
this new and different configuration or assemblage, new desires, questions or quests. Spirituality in terms of 'patterns of becoming' and the development of what Braidotti, in Metamorphoses: Towards a Materialist Theory of Becoming, calls a 'rhizomic sensibility' in educational spaces, inevitably resists 'more of the same' and in this way provides an answer to those critics who - whether negatively or positively - can only understand spiritual needs and development in terms of static or essentialized values and knowledges.

But if the pathway opened up by becoming or nomadic spirituality is, as it were, inspiring, it is also important to recognize that it entails risk. There is invariably strong resistance to change or to the emergent and new, and what is normative is, by definition, hard to identify prior to disembedding. For example, bell hooks refers to the apparently common-sense notion that a class room should be a 'safe' and harmonious place. This view is a deeply rooted educational value that at its best, addresses forms of unfairness and bullying. Yet what the privileging of safety over every other consideration may hide, is the implicit violence of embedded normative exclusions, discrimination and unconscious bias that can make educational spaces de-spiriting or even dangerous for those who are excluded from its privileges and refused space to challenge and contest loudly or disruptively. In Teaching to Transgress hooks talks about the difficulties her African American students from working class backgrounds, for example, encountered in predominantly white, middle class college classrooms and other educational spaces still subject to the hegemony of white middle class male values and expectations. The stakes can be high; in response to the challenges she faced in classroom experiments addressed to racial disadvantage, for example, hooks acknowledges that upheaval is part and parcel of any change:

...[in] all cultural revolutions there are periods of chaos and confusion, times when grave mistakes are made. If we fear mistakes, doing things wrongly, constantly evaluating ourselves, we will never make the academy a culturally diverse place where scholars and the curricula address every dimension of that difference. ${ }^{48}$

In other words, finding spaces in which to breathe freely, touching or engaging, for exam- ple with marginal knowledges in public spaces and in this way calling a whole established way of doing things into question is frequently dangerous. The punk band Pussy Riot, for

47. hooks b (1994) Teaching to Transgress: Education as the Practice of Freedom. New York \& London: Routledge.

48. hooks b (1994) Teaching to Transgress: Education as the Practice of Freedom. New York \& London: Routledge 33.

example, mobilized public opinion and generated discussions across continents with their highly physical, provoking performances. But, of course, whilst they gained wide media coverage for their scandalous public trial and their 
impressively intelligent responses to their inquisitors, two of the group spent nearly two years in the appalling conditions of Russian penal colonies for their trouble. ${ }^{49}$ Pussy Riot, an all female Punk collective formed in Moscow in 2011, wrote songs and music that were vehement, outspoken pro- tests against the administration of the Russian President. They came to international prominence in 2012 when they challenged the collaboration between the Kremlin and the Orthodox Church against sexual nonconformity, by performing their 'punk prayer', claiming Moscow's Christ the Saviour Cathedral for their public seminar on challenging sameness and letting the difference/s in. They defied the dominant heteropatriarchal sub- ject by dispelling the illusion of Russia as a safe and harmonious place; revealing that there was a different story to tell for sexual nonconformers amongst other dissidents in their country. If RE is to become a practical and policy context within which to initiate the kind of concern with marginal knowledges and with calling totalizing frameworks into question that opens people up to difference/s and to the transformations they entail, it is likely that these alternate visions won't please everyone! It is, of course, often much easier to conform than, even tentatively, to question the real purposes - rather than the effective- ness - of our day to day teaching practices; to question for example, whether is it always a good thing to produce extensive paperwork setting out specific outcomes and goals in advance of beginning any teaching course. However, in reflecting on how rather small 'transgressions' that might be initiated at this level - deliberately setting out on small journeys in limited classroom contexts with an open mind as to what one might learn or to where one is going, for example - might take considerable effort and courage to sus- tain, we perhaps need to remain alert to how more provoking gestures in the name of nomadic spirituality, though they would perhaps allow us to breathe more deeply in newly opened up public spaces, would undoubtedly also tempt more punitive responses.

\section{Conclusions ... Becoming Spirituality}

So, what I have done here is to set out a very brief introduction to some of the complexi- ties and obstacles to effecting feminist-friendly changes in the public domain of educa- tion with specific reference to the field of Religion/Religious Studies or TRS within which I work - and presently earn a living. I have suggested an approach to change based on the mobilization of spirituality characterized in terms of becoming towards difference/s - as one metaphor that has been grasped to effect in the past by pioneers such as Carol Christ and Judith Plaskow to bring about changes, initially in the western theological academy of the 20th century but through wide dissemination and some popu- lar acclaim, also in broadly associated spaces such as UK RE in the 21 st century. This imaginative work has evoked for me the fruitful metaphor of spirituality to initiate and sustain the process of thinking through how to claim educational spaces identified with 
'religion', class-rooms, academic curricula, or the work of policy makers for a more liberating embodied praxis that can avoid falling into too many traps - for example posed by gendered stereotypes or assumptions - that frustrate our abilities to explore the widest possibilities of difference/s and lead us back into constructions of sameness such as essentialized notions of religion, spirituality and the secular that typically exclude sig- nificant aspects of experience or forms of representation associated with women and privilege disembodied masculine rationality, principles of divinity or neoliberal ideologies.

What then finally of the question raised in the title? Does the metaphorical content of Christ and Plaskow's title - read here consciously against normative understandings - still ring true and do we have the capacity to make changes to something like current UK policies on RE, in such ways as seem fit for feministfriendly purposes for the present and future? Christ and Plaskow, of course, went on after producing and publishing Womanspirit Rising to publish in 1989 another collection Weaving the Visions: New Patterns in Feminist Spirituality in which they sought to address the shortfall of the pre- vious volume. They have also acknowledged their own struggles with difference/s; an honest avowal of jealousies, competitiveness and painful divergences, changing the met- aphor from raising spirits to weaving and seeing visions, but still claiming educational spaces for new adventures in boundary crossing and letting the difference/s in. Their work then stands as a kind of inspiration for continuing feminist theory and analysis within RE as part of a process of expanding capacity in public spaces to engage with difference/s of every kind in an ever changing process that seeks to help children young people and all other stakeholders articulate their different desires, purposes and trans- formative visions for both their own and the common good. 